\title{
CLINICAL STUDIES OF PHENYLBUTAZONE (BUTAZOLIDIN) AND BUTAPYRIN (IRGAPYRIN) IN RHEUMATOID ARTHRITIS, RHEUMATOID SPONDYLITIS, AND GOUT*
}

BY

\author{
E. G. KIDD, $\uparrow$ K. C. BOYCE, $\uparrow$ and R. H. FREYBERG \\ From the Hospital for Special Surgery and Cornell University Medical College, New York, N.Y.
}

(RECEIVED FOR PUBLICATION JANUARY 6, 1953)

Clinical trials of two drugs new to the American continent, phenylbutazone (Butazolidin) and butapyrin, were begun with the assumption that any beneficial effect from them in various rheumatic diseases would be chiefly that of producing analgesia. As the studies progressed it became apparent that the drugs had more than an analgesic action in acute gouty arthritis, that studies of butapyrin could be discontinued, and that the investigation could be focused on phenylbutazone.

"Butazolidin" is the trade name for phenylbutazone, a totally new compound originally used in Europe as a solubilizing agent for various analgesics given by intramuscular injection, notably for dimethylamino-antipyrin (aminopyrin). Butapyrin (marketed in some countries under the name of "Irgapyrin') is a simple mixture of equal parts of phenylbutazone and dimethylamino-antipyrin (Fig. 1). A short bibliography of selected references in the literature to the use of these drugs is given below.

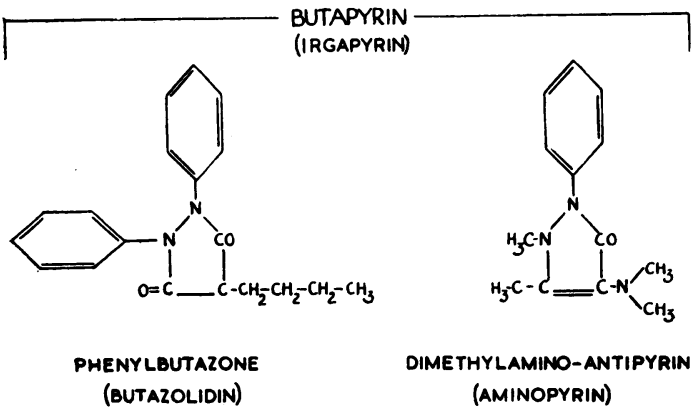

Fig. 1.-Structural formulae of phenylbutazone (Butazolidin) and butapyrin (Irgapyrin).

\footnotetext{
* Read, in part, at the meeting of the American Rheumatism Association Chicago, Illinois, June 8,1952 . These studies were supported by the Fund for Research in Rheumatic Diseases, Hospital for Special Surgery.

Surgery. and $\mathbf{R h e u m a t i s m}$ Association.
}

\section{Method of Investigation}

Phenylbutazone was given clinical trial in 51 patients with rheumatoid arthritis, thirteen with rheumatoid 을 spondylitis, and sixteen with acute gouty arthritis. Experi- ence with butapyrin was similar, but less extensive $z$ (Table I). A critical comparison was made between the initial and subsequent observations of the patients inves- $\frac{\hat{S}}{\square}$ tigated, from both the subjective and objective viewpoint. $\vec{\rho}$ Repeated urine analyses were made on all patients in the $f$ early portion of the study. In cases where the degree of $\omega$ clinical improvement warranted it, the erythrocyte sedimentation rates were measured. In many cases of gout, the plasma and urinary uric acid were determined.

TABLE I

PATIENT-TRIALS OF PHENYLBUTAZONE (BUTAZOLIDIN) AND BUTAPYRIN IN VARIOUS RHEUMATIC DISEASES

\begin{tabular}{|c|c|c|c|c|}
\hline \multirow{2}{*}{ Condition } & \multicolumn{2}{|c|}{ Patients } & \multicolumn{2}{|c|}{ Trials } \\
\hline & $\begin{array}{l}\text { Phenyl- } \\
\text { butazone }\end{array}$ & $\begin{array}{l}\text { Buta- } \\
\text { pyrin }\end{array}$ & $\begin{array}{c}\text { Phenyl- } \\
\text { butazone }\end{array}$ & $\begin{array}{l}\text { Buta- } \\
\text { pyrin }\end{array}$ \\
\hline 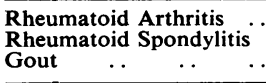 & $\begin{array}{l}51 \\
13 \\
16\end{array}$ & $\begin{array}{r}18 \\
3 \\
3\end{array}$ & $\begin{array}{l}52 \\
13 \\
36\end{array}$ & $\begin{array}{r}18 \\
3 \\
4\end{array}$ \\
\hline Totals & 80 & 24 & 101 & 25 \\
\hline
\end{tabular}

Butapyrin was supplied in 250-mg. tablets, and was 으 administered in doses of 500 to $1,000 \mathrm{mg}$. daily, usually divided into two or three doses. Butazolidin was supplied $\frac{7}{0}$ in $200-\mathrm{mg}$. tablets, and was given orally, 400 to $800 \mathrm{mg}$. daily, in divided doses; it was also supplied in a 20 per N cent. solution which was given intramuscularly in doses of 400 to $1,000 \mathrm{mg}$. once or twice daily. When given 0 orally, these drugs were administered immediately after $\mathcal{\omega}$ meals, for trial showed that gastro-intestinal irritation $\sigma$ was minimized when the drug was taken when there was food in the stomach.

\section{Results}

Therapeutic.-The symptomatic relief of pain and 0 stiffness is shown in Table II. In patients with rheu-

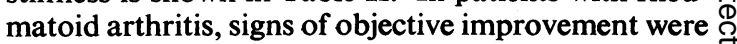
infrequent, and when observed, consisted chiefly $\stackrel{\mathbb{Q}}{\varrho}$ 
of improvement in the function of affected joints (increase in range or ease of motion). In a few rheumatoid arthritics who experienced marked symptomatic relief, there was definite decrease in the signs of synovitis. However, reduction in the clinical signs of inflammation occurred in each patient with acute gouty synovitis, and closely paralleled the subjective benefit consistently observed. In patients with gout, symptomatic relief began within $24 \mathrm{hrs}$, in contrast to the usual slower onset of relief (within 7 days) in patients with rheumatoid arthritis.

TABLE II

INCIDENCE OF SIGNIFICANT SUBJECTIVE IMPROVEMENT FROM PHENYLBUTAZONE AND BUTAPYRIN IN PATIENTS WITH VARIOUS RHEUMATIC DISEASES

\begin{tabular}{|c|c|c|c|c|c|c|c|}
\hline Drug & . & .. & $\cdots$ & \multicolumn{2}{|c|}{ Phenylbutazone } & \multicolumn{2}{|c|}{ Butapyrin } \\
\hline $\begin{array}{r}\text { Degre } \\
\text { (per }\end{array}$ & f Im & $\begin{array}{c}\text { provemen } \\
\ldots\end{array}$ & t. & Moderate & Marked & Moderate & Marked \\
\hline Rheun & oid & Arthritis & . & 32 & $10 \cdot 6$ & $33 \cdot 3$ & $22 \cdot 3$ \\
\hline Rheun & oid & Spondyli & & 23 & $61 \cdot 5$ & 0 & 100 \\
\hline Gout & . & . & . & $13 \cdot 9$ & $58 \cdot 4$ & 0 & 75 \\
\hline
\end{tabular}

It is apparent from Table II that marked benefit occurred much more often in patients with acuite gouty arthritis and rheumatoid spondylitis than in those with classical rheumatoid arthritis. It should be noted that the marked improvement seen with butapyrin, which occurred in a high percentage of patients with spondylitis and gout, was duplicated later, in each instance, by an equally good result with the use of phenylbutazone.

Toxic.-The undesirable effects ("toxicity") found in this investigation were similar in nature for both drugs, but were more numerous with butapyrin68 per cent. v. $26 \cdot 7$ per cent. (Table III). Quite often the disturbances were sufficiently severe to require discontinuance of the drug. The most frequent and troublesome undesirable effects were nausea, anorexia, vomiting, epigastric pain, and diarrhoea, in that order of frequency. Erythematous dermatitis, patchy or generalized, and usually non-pruritic, sometimes necessitated discontinuance of the drug. One pharmacologic action of butapyrin is the production of sodium and water retention. Phenylbutazone may be largely responsible for this, because gain in weight invariably occurred when Butazolidin was administered. Observable oedema was less frequent, and was rarely troublesome. Drowsiness was reported occasionally.

These undesirable effects, particularly the gastrointestinal disturbances, were sufficiently frequent to hamper our studies, and it was often necessary to discontinue the oral use of these drugs. Of fourteen
TABLE III

UNDESIRABLE EFFECTS FROM PHENYLBUTAZONE AND BUTAPYRIN

\begin{tabular}{|c|c|c|c|}
\hline Condition & Undesirable Effects & $\begin{array}{l}\text { Phenyl- } \\
\text { butazone }\end{array}$ & $\begin{array}{l}\text { Buta- } \\
\text { pyrin }\end{array}$ \\
\hline $\begin{array}{l}\text { Rheumatoid } \\
\text { Arthritis }\end{array}$ & $\begin{array}{l}\text { Gastro-intestinal disturbances } \\
\text { Oedema } \\
\text { Dermatitis }\end{array}$ & $\begin{array}{r}14^{*} \\
5 \\
3\end{array}$ & $\begin{array}{c}12 \dagger \\
2 \\
3\end{array}$ \\
\hline $\begin{array}{l}\text { Rheumatoid } \\
\text { Spondylitis }\end{array}$ & $\begin{array}{l}\text { Gastro-intestinal disturbances } \\
\text { Oedema } \\
\text { Dermatitis }\end{array}$ & $\begin{array}{l}2 \ddagger \\
0 \\
1\end{array}$ & $\begin{array}{l}\mathbf{0} \\
\mathbf{0} \\
\mathbf{0}\end{array}$ \\
\hline Gout & $\begin{array}{l}\text { Gastro-intestinal disturbances } \\
\text { Oedema } \\
\text { Dermatitis }\end{array}$ & $\begin{array}{l}1 \S \\
0 \\
1\end{array}$ & $\begin{array}{l}\mathbf{0} \\
\mathbf{0} \\
\mathbf{0}\end{array}$ \\
\hline Totals & . & 27 & 17 \\
\hline Percentage & & $26 \cdot 7$ & 68 \\
\hline
\end{tabular}

Intolerance was not usually related to size of daily dose.

- Exacerbation of duodenal ulcer symptoms (one patient).

+ Peptic ulcer symptoms and $x$-ray demonstration of duodenal ulcer occurred without previous known ulcer (one patient).

$\ddagger$ Haematemesis thought to be due to diaphragmatic hernia (one patient).

$\S$ Exacerbation of duodenal ulcer symptoms (one patient).

patients given phenylbutazone intramuscularly, none showed any gastro-intestinal disturbance, and one patient who had had a proven duodenal ulcer, tolerated parenteral phenylbutazone after its use orally had caused significant gastro-intestinal disturbance. The appearance of one or more of these undesirable effects was the chief reason for discontinuance of the drug in 20 per cent. of patients given phenylbutazone and in 68 per cent. of patients given butapyrin. Although it is possibly more effective as an analgesic agent, we discontinued our studies of butapyrin and focused our attention on phenylbutazone because the latter drug provided similar benefits, with fewer and less severe signs of toxicity.

The absorption of phenylbutazone from the gastro-intestinal tract was studied by using tablets which had different types of coating used in an effort to lessen or eliminate the nausea and indigestion. There was considerable difference in degree of absorption with the different types of tablets and the data is still inadequate to allow satisfactory selection to be made. The problem is being studied further in connection with determinations of phenylbutazone concentration in the blood and urine. In a few cases gelatin capsules gave results superior to those from any coated tablets.

\section{Laboratory Studies}

Weekly or bi-weekly blood counts were done on all patients receiving these agents. No instance of anaemia that could not be accounted for by factors other than the drug was observed. Leucopenia, granulopenia, or thrombocytopenia and purpura did not occur in our patients. * There was one instance of transient albuminuria and one of microscopic haematuria. These urinary

* See Addendum below p. 23. 
abnormalities may not have been the result of the drugs. In the cases of rheumatoid arthritis or spondylitis where subjective improvement was marked or where significant objective improvement occurred, the erythrocyte sedimentation rates did not decrease sufficiently to indicate that the rheumatoid activity had been altered.

In one patient, detailed laboratory tests were performed before and during phenylbutazone therapy, to determine whether there was any effect on hepatic or renal function, or on carbohydrate metabolism. Results indicated no harmful effect on hepatic or renal function, and no changes in acid-base balance, serum sodium, potassium, and chlorides. The patient showed the expected gain in body weight, which was apparently due to sodium and water retention (electrolyte balance studies were not done). There was no change in glucose tolerance.

\section{Effects in Patients with Gout}

The action of phenylbutazone in patients with gout deserves special attention because:

(1) it produces rapid and excellent clinical improvement in a high percentage of patients with acute gouty arthritis,

(2) it affects the plasma uric acid levels.

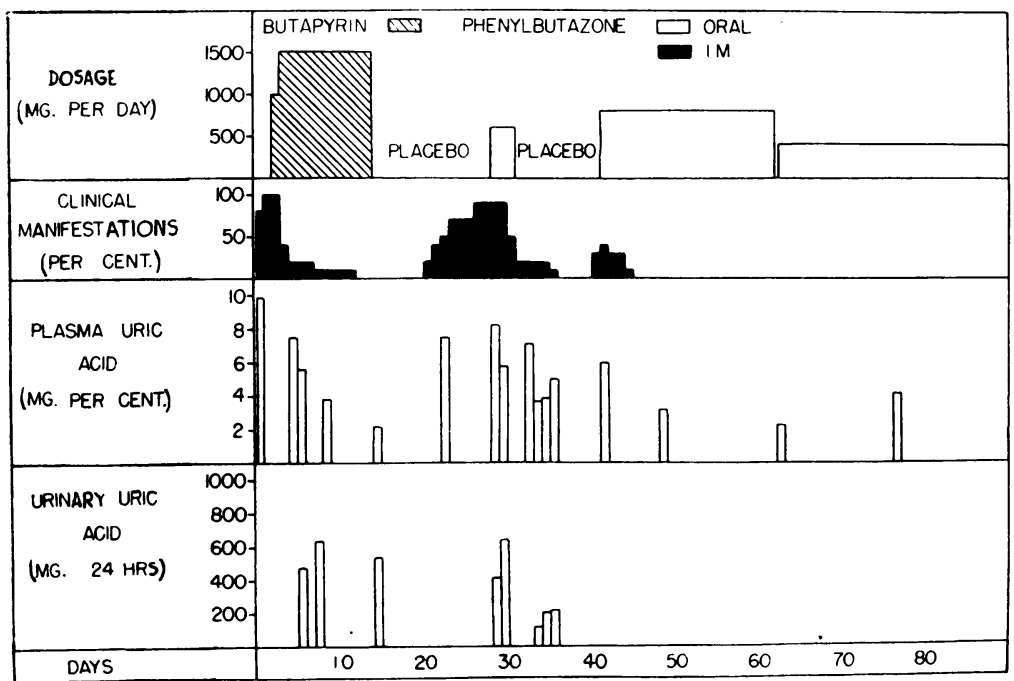

Fig. 2.-Example of the effect of butapyrin and phenylbutazone in a patient with gouty arthritis.

Sixteen patients with gout were studied through forty attacks of acute gouty arthritis. Of these attacks, 36 were treated with phenylbutazone (27 orally and 9 intramuscularly), and four with butapyrin. Thirty of these attacks were suppressed rapidly and completely, and there were ten treatment failures with oral phenylbutazone or butapyrin. Three of these occurred in patients who subsequently derived marked benefit from phenylbutazone intramuscularly. In four patients failures occurred at a time when Benemid was being administered simultaneously; two of these patients experienced the usual remarkable benefit from phenylbutazone during subsequent attacks-after administration of Benemid had been discontinued. Two patients had trials only with oral phenylbutazone and no opportunity presented to treat subsequent attacks with this medicine intramuscularly. One gouty patient had an excellent response to phenylbutazone given orally in the first attack, but later attacks failed to respond to the oral or intramuscular administration of the drug.

From these experiences it appears that:

(1) There may be some antagonistic action between Benemid and phenylbutazone, at least in some gouty patients. These two agents have quite different effects on uric acid metabolism, so that in some circumstances the beneficial effect of phenylbutazone may be prevented by Benemid.

(2) For treatment of acute attacks of gouty arthritis, the intramuscular injection of phenylbutazone is more dependable than its use orally.

From the outset of these studies it was noted that in many gouty patients there was a marked decrease in the plasma concentration of uric acid shortly after phenylbutazone or butapyrin was administered. Plasma uric acid values were determined in fifteen patients with gout, and urinary uric acid excretion was measured in nine. A significant decrease ( $2 \mathrm{mg}$. or more) was seen in the plasma uric acid concentration in twelve of the fifteen patients; the maximum reduction being $7.8 \mathrm{mg}$. (minimum $2 \cdot 3$, average $3.5 \mathrm{mg}$. per cent.). Patients who had marked hyperuricaemia invariably showed greater reductions in the plasma uric acid con- $N$ centration (Fig. 2). In nine patients with uncontrolled $\mathrm{C}^{2}$ diets there was no significant increase in output of urinary uric acid. This suggests that the decrease in plasma concentration of uric acid may not be due to a uricosuric action of this drug.

In thirteen non-gouty patients who had been receiving phenylbutazone, the average plasma uric acid value was $1.8 \mathrm{mg}$. per cent. (the average in our laboratory for non-gouty patients is above $3 \mathrm{mg}$. per cent.). Typical examples of reductions in the 
plasma uric acid percentage during treatment in three patients with rheumatoid arthritis are:

(1) before phenylbutazone, $4.5 \mathrm{mg}$; after, $1.6 \mathrm{mg}$.

(2) before phenylbutazone, $2.4 \mathrm{mg}$; ; after, $1.2 \mathrm{mg}$.

(3) before phenylbutazone, $5.0 \mathrm{mg}$.; after, $1.7 \mathrm{mg}$.

Since there was no ready explanation for the decrease in plasma uric acid in gouty and non-gouty individuals receiving phenylbutazone, it seemed logical to wonder whether this drug caused destruction of uric acid. After satisfying ourselves by repeated tests, that the method for determination of uric acid was accurate, a series of in vitro experiments were performed to help to clarify this problem.

Experiment 1.-A reading for uric acid value was obtained on a standard solution of uric acid and on a sample of plasma from a patient receiving phenylbutazone orally. A measured amount of this uric acid solution was then added to the plasma and a reading again obtained. Aliquots of this solution were then stored, with controls in each instance, for $24 \mathrm{hrs}$ at $37^{\circ} \mathrm{C}$., at room temperature, and in a deep freeze, and the readings for uric acid values again were repeated. There was no significant decrease in the uric acid content of the test solution on comparison with the controls. Thus, the plasma of a patient receiving phenylbutazone orally contained no agent that destroyed uric acid in vitro.

Experiment 2.-Crystalline uric acid was added to the plasma of a patient who had received $200 \mathrm{mg}$. phenylbutazone by intramuscular injection $2 \mathrm{hrs}$ before the blood specimen was obtained. A reading for uric acid was made on the original (control) plasma and on the plasma after the addition of crystalline uric acid. Aliquots of both control and test solutions were stored for $24 \mathrm{hrs}$ at $37^{\circ} \mathrm{C}$., at room temperature, and in a deep freeze. Again analyses showed no evidence that the plasma contained any agent that lowered the uric acid value of an artificially produced "hyperuricaemic plasma" in vitro.

Experiment 3.--Increasing amounts of a solution of phenylbutazone were added to equal volumes of a standard uric acid solution. Readings of uric acid were made before and after the addition of phenylbutazone showed no significant change, regardless of the amount of drug added. This, again, indicates that phenylbutazone had no discernible effect on the uric acid content of solutions in vitro.

Experiment 4.-Specimens of normal plasma and plasma from patients receiving phenylbutazone were obtained and their plasma uric acid concentration was determined. The specimens were then mixed, and the uric acid content of the mixed solution was determined. Aliquots control and solutions were stored at $37^{\circ} \mathrm{C}$. for $24 \mathrm{hrs}$, and the uric acid content was again determined. No evidence was found that the "phenylbutazone plasma" could thus destroy plasma uric acid in vitro.

\section{Summary}

Clinical trials with phenylbutazone (Butazolidin) and butapyrin (Irgapyrin) were made in patients with rheumatoid arthritis, spondylitis, and gout. Phenylbutazone is a potent analgesic agent in certain patients with rheumatoid arthritis, and some tolerate it well and have derived benefit for as long as
9 months. Its oral use, however, is limited in some patients by undesirable side-effects, mostly gastrointestinal disturbances. Oedema is rarely a problem, but the drug is contraindicated in patients with a tendency to oedema due to cardiac, renal, or hepatic disease. Although no instances of blood dyscrasia were observed among our patients, precautions should be taken for their detection. Gastrointestinal symptoms were not observed when phenylbutazone was given intramuscularly, but irritation may occur at the site of injection, and the need for injections daily or every second day to sustain benefit makes this method of administration impractical in rheumatoid patients.

Very good clinical results from phenylbutazone were usually obtained in patients with rheumatoid spondylitis.

In patients with acute gouty arthritis, phenylbutazone usually gave rapid and dramatic results, often superior to those obtained with other agents (i.e. colchicine and corticotrophin). The suggested ability of phenylbutazone to lower the plasma uric acid without significant uricosuric effect is unique. This phenomenon must be studied more carefully; it may be a key to further understanding of the fundamental metabolic defect in gout.

Any additional benefit from the mixture of phenylbutazone and aminopyrin (butapyrin) is far outweighed by the greater incidence and severity of undesirable side-effects and by the hazards of administration.

Studies of the plasma concentration of phenylbutazone correlated with dosage and clinical results may help to decrease the undesirable side-effects and improve the value of this drug.

The phenylbutazone (Butazolidin) and butapyrin used in these investigations were generously supplied by Geigy Pharmaceuticals, Inc., N.Y., through the kindness of Dr. A. Hemming, to whom we express our appreciation and thanks.

\section{Addendum}

Since this report was submitted for publication the authors have learned of one instance of aplastic anaemia and of four instances of granulopenia following administration of phenylbutazone (Stifel and Burnheimer, 1953; Bershof and Oxman, 1953).

\section{BIBLIOGRAPHY}

Belart, W. (1949). Schweiz. med. Wschr., 79, 582.

Bershof, E., and Oxman, A. C. (1953). J. Amer. med. Ass., 151, 557. Currie, J. P. (1952). Lancet, 2, 15.

Domenjoz, R. (1952). Fed. Proc. 11, 339.

Fabre, J., and Mach, R. S. (195i). Schweiz. med. Wschr., 81, 473.

Fischer, H. (1951). Dtsch. med. Wschr., 76, 50.

Fischer, H. (1951), Otsch. med. Wschr., 76, 50.

Hart, F. D., and Johnson, A. M. (1952). Lancet, 2, 43.

Jaques, R., and Domenjoz, R. (1950). Arch. exp. Path. Pharmak., 212, 124.

Kuzell, W. C. (1951). Annu. Rev. Med., 2, 367.

, Schaffarzick, R. W., Brown, B., and Mankle, E. A. (1952). J. Amer. med. Ass., 149, 729. 
Seliger, H. (1951). Ärztl. Wschr., 6, 89.

Steinbrocker, O., Berkowitz, S., Ëhrlich, M., Elkind, M., and Carp, S. (1952). J. Amer. med. Ass., 150, 1087.

Stephens, C. A. L., Yeoman, E. E., Holbrook, W. P., Hill, D. F., and Goodin, W. L. (1952). Ibid., 150, 1084.

Stifel, J. L., and Burnheimer, J. C. (1953). J. Amer. med. Ass., 151, 555 .

Etudes cliniques du phénylbutazone (Butazolidin) et de la butapyrine (Irgapyrin) dans l'arthrite rhumatismale, la spondylite rhumatismale et la goutte

RÉSUMÉ

On procédà â des essais cliniques du phénylbutazone (Butazolidin) et de la butapyrine (Irgapyrin) chez des malades atteints d'arthrite rhumatismale, de spondylite, et de goutte. Le phénylbutazone est un agent analgésique puissant chez certains malades atteints d'arthrite rhumatismale et il y en a qui l'ont bien toléré et s'en sont bien trouvés pendant des périodes allant jusqu'à 9 mois. Son emploi par voie buccale est cependant limité par des effets secondaires, surtout des troubles gastrointestinaux. L'oedème présente rarement un problème, mais ce médicament est contre-indiqué chez des malades avec une tendance à l'oedème d'origine cardiaque, rénale ou hépatique. Bien qu'on n'aie pas observé de cas de dyscrasie sanguine, il faut les dépister. Après l'administration intramusculaire du phénylbutazone on ne voit pas de troubles gastro-intestinaux, mais une irritation à l'endroit de l'injection peut apparaître; la valeur pratique de la voie intramusculaire s'en trouve diminuée, car pour maintenir l'amélioration chez les rhumatisants il faudrait faire des injections quotidiennes ou tous les deux jours.

De très bons résultats cliniques furent généralement obtenus avec le phénylbutazone chez les malades atteints de spondylite rhumatismale.

Dans les cas d'arthrite goutteuse aiguë le phénylbutazone donnait généralement des résultats rapides et frappants, souvent supérieurs è ceux obtenus avec d'autres agents ( $p$. ex. colchicine et corticotrophine). Le pouvoir apparent du phénylbutazone de faire baisser le taux de l'acide urique dans le plasma sans produire un effet uricosurique signifiant est exceptionnel. Ce phénomène pourrait aider à expliquer l'essence du trouble métabolique dans le goutte.

Tout avantage d'un mélange de phénylbutazone et de butapyrine s'évanouit devant la fréquence et la sévérité des effets secondaires qui en résultent et devant les dangers posologiques.

L'étude des variations du taux sanguin du phényl- butazone selon les doses et les résultats cliniques peut aider à réduire les effets secondaires nuisibles et donc à rendre ce médicament plus utile.

Estudios clínicos del fenilbutazone (Butazolidin) y de la butapirina (Irgapyrin) en la artritis reumatoide, la espondilitis reumatoide $y$ en la gota

\section{Sumario}

Se hizo ensayos clínicos del fenilbutazone (Butazolidin) y de la butapirina (Irgapyrin) en enfermos con artritis reumatoide, espondilitis, y gota. El fenilbutazone es un analgésico poderoso en ciertos enfermos con artritis reumatoide; algunos le toleraron bien y le tomaron con provecho durante períodos que se extendían a veces hasta 9 meses. Sin embargo, efectos secundarios nocivos, ante todo disturbios gastro-intestinales, limitan su empleo por vía oral. El edema es un problema poco frecuente, pero este producto no debe administrarse á enfermos con tendencia al edema cardiaco, renal $o$ hepático. Aunque no se hubiese encontrado casos de discrasia sanguínea entre los enfermos estudiados, es menester de buscarlos. Después de la administración intramuscular del fenilbutazone no se vieron disturbios gastrointestinales, pero una irritación en el sitio de la inyección puede aparecer, lo que reduce el valor práctico de esta vía, ya que se necesitan inyecciones diarias o cada dos días para mantener la mejoría en los reumáticos.

Se obtuvieron generalmente muy buenos resultados con el fenilbutazone en casos de espondilitis reumatoide.

En casos de artritis gotosa aguda el fenilbutazone producía generalmente resultados rapidos y dramáticos, a veces superiores a los obtenidos con otros medicamentos (p. ej. colchicina y corticotrofina). El fenilbutazone tiene el poder aparente, que es excepcional, de hacer bajar la tasa del ácido úrico del plasma sin producir un efecto uricosúrico significante. Este fenómeno ofrece quizás la llave del problema del disturbio metabólico fundamental en la gota.

Las ventajas de un mezcla de fenilbutazone y de butapirina desaparecen frente a la mayor frecuencia y gravedad de los efectos secundarios y a los peligros posológicos.

El estudio de las variaciones de la tasa sanguínea del fenilbutazone en correlación con las dosis y los resultados clínicos podría contribuir a la reducción de los efectos secundarios nocivos, aumentando así el valor del medicamento. 